Economic Structure and Development in an Emergent Asian Economy Evidence from a Social Accounting Matrix for Vietnam

Tarp, Finn; Roland-Holst, David; Rand, John

Published in:

Journal of Asian Economics

Publication date:

2003

Citation for published version (APA):

Tarp, F., Roland-Holst, D., \& Rand, J. (2003). Economic Structure and Development in an Emergent Asian Economy: Evidence from a Social Accounting Matrix for Vietnam. Journal of Asian Economics, 13(6). 


\title{
Economic Structure and Development in an Emergent Asian Economy: Evidence from a Social Accounting Matrix for Vietnam
}

\author{
Finn Tarp* \\ University of Copenhagen and CIEM \\ David Roland-Holst \\ Mills College \\ John Rand \\ University of Copenhagen
}

\begin{abstract}
Vietnam started a wide-ranging process of economic reform in 1986 and is presently opening up its economy to regional and global economic forces. As a result, Vietnam faces significant challenges in the area of economic policy analysis in spite of a remarkable growth performance in recent years. This paper reviews insights emerging from a detailed social accounting matrix (SAM), compiled for the year 2000. The SAM reflects Vietnam's heavy reliance on primary sector activities, but we also find that agricultural potential could be expanded significantly. In other sectors, the critical importance of sustained commitments to human capital development is apparent. In this context, the international donor community can support the ongoing transformation process through concerted training and capacity building initiatives that have proven successful elsewhere in the region.
\end{abstract}

JEL classification: C69, C82, O1, O53

Keywords: Social Accounting Matrix, Economic Development, Vietnam

\footnotetext{
* Finn Tarp is Senior NIAS Researcher at CIEM in Hanoi and Associate Professor at the University of Copenhagen. David Roland-Holst is Professor of Economics at Mills College, and John Rand is Ph.D. student at the University of Copenhagen. Opinions expressed here are those of the authors and should not be attributed to their affiliated institutions. We would like to express our gratitude for excellent comments from two anonymous referees. Contact: Finn Tarp, Institute of Economics, University of Copenhagen, Studiestræde 6, DK-1455 Copenhagen K, Denmark. Phone (+45) 353230 41, fax +45) 353230 00, e-mail: Finn.Tarp@econ.ku.dk
} 


\section{Introduction}

Vietnam has come a long way since the doi moi reform process was initiated in 1986 (see Le Dang Doanh, 2000). The past 15 years have witnessed one of the best performances in the world in terms of both economic growth and poverty reduction. People's living standards have improved significantly, and the country's socioeconomic achievements are impressive from a human development perspective. Wide-ranging institutional reform has been introduced, including a greater reliance on market forces in the allocation of resources and the determination of prices. An ongoing shift from an economy dominated by the state and co-operative sectors to greater prominence of private sector and foreign investment activity in GDP can also be noted. Important strides have been made over a relatively short time span to further the transition from a centrally planned to a socialist market economy. Nevertheless, Vietnam remains a poor country. How the country can rapidly and sustainably transform itself and its economy to a more modern society remains a critical policy challenge.

In parallel with domestic reforms in the agriculture, industry and service sectors, Vietnam has started a process of opening up its economy to regional and global economic forces, including reliance on foreign direct investment, that will shape the environment in which the future growth process of Vietnam will have to take place. Vietnam joined the Association of South East Asian Nations (ASEAN) in 1995, and is also a member of the Asia-Pacific Economic Co-operation (APEC). The central economic and trade program of co-operation for ASEAN is the ASEAN Free Trade Area (AFTA), and AFTA's key instrument is a Common Effective Preferential Tariff (CEPT). By joining ASEAN, Vietnam has therefore already undertaken international commitments in the area of trade policy, which are bound to have a profound impact on opportunities for economic development. This is particularly so in light of the intense competition that characterizes today's global markets, and the attendant rapid evolution and diffusion of science and technology. To understand the impact of these choices and come up with appropriate responses are critical tasks for Vietnamese policymakers. The same goes for commitments to other trade initiatives like the World Trade Organization (WTO) and the recent bilateral trade agreement (BTA) with the US.

While the progress achieved over the past 15 years is indeed remarkable in the modern history of Vietnam, it is clear that Vietnam faces tremendous challenges in the area of economic policy analysis. Appropriate policy advice cannot be formulated without adequate and timely data and information on the structure of the economy. For this reason, a detailed social accounting matrix (SAM) for the Vietnamese 
economy was recently compiled for the year $2000 .{ }^{1}$ The SAM is a disaggregated tableau that provides closed form, economy-wide accounting of linkages between activities, commodities, factors, households, domestic institutions, and foreign institutions in a tabular format that is both transparent and amenable to multiplier analysis similar to that introduced by Leontief. ${ }^{2}$

In this paper, we demonstrate what can be learned from direct inspection of the Vietnam SAM. The purpose is both pedagogical and practical. Far from being a static picture or "time slice" of an economy in transition, the structure of the 2000 SAM reveals much about the economic past, present, and future potential of Vietnam. The paper is organized as follows. After this introduction, Section 2 outlines the analytical framework; reviews data sources, and identifies macroeconomic features of the Vietnamese economy. Section 3 presents the structure of supply and demand as well as value added and the distribution of factor income, and Section 4 discusses import and export. In these two sections we also provide some evaluation of the impact of government policies directed at agricultural, industrial, and services development as well as the role of private-sector activities, including foreign direct investment. Section 5 concludes.

\section{Analytical Framework and Data}

Traditional physical input-output (I/O) analysis was characteristic of central planning in the past. However, in modern economy-wide studies, Social Accounting Matrices (SAMs) and Computable General Equilibrium (CGE) models that take account of supply and demand behavior and the mediating role of market institutions have become the analytical tools of choice in supporting economy-wide policy design and implementation. An interesting SAM for Vietnam was published by the United Nations already in the mid-1990s. ${ }^{3}$ While much of the theoretical analysis and overview in that document remains valid, it is very aggregated and relies on a now outdated 1989 10-sector I/O table. Various other contributions to this area of work exist, including for example Bautista (2000) and Huong (2000), but the 2000 Vietnam SAM breaks new ground. It reflects the economic structure of Vietnam in the aftermath of the Asian financial crisis and brings together the following contemporaneous and unified information in an extensive manner: (i) National

\footnotetext{
1 The complete SAM is documented in Tarp, Roland-Holst, Rand and Jensen (2002).

2 Background references on SAM methodology are Pyatt and Round (1985) and Reinert and RolandHolst (1997).

${ }^{3}$ The major purpose of estimating the SAM was to develop a coherent data framework underlying a set of macroeconomic policy-simulations and short-term forecasting exercises. For example, the SAM was used to implement a model designed to evaluate the impact of alternative modes of financing possible increases in the government wage bill. Hence, the focus of the UN SAM was very aggregate in nature (United Nations, undated).
} 
income and product accounts; (ii) Detailed sector accounts and I/O information; (iii) Employment and earnings data; (iv) Multilateral partner trade data; and (v) Directly sampled and nationally representative household survey data. In what follows, we discuss these data sources, their reliability and the methods involved in more detail.

Before examining more disaggregated SAM accounts, we provide as point of departure two tables which demonstrate how macro-data can be organized in a SAM format and one table which identifies the macro-features of the 2000 Vietnamese SAM. Tables 1-3 are essentially double entry representations of the usual macroeconomic accounting identities. Table 1 depicts an open-economy MacroSAM with a government sector in terms of the macro accounting identities. Note that in this case intermediate goods are netted out. ${ }^{4}$ With these macro accounts in mind, Table 2 includes a tableau of generic SAM accounts for Vietnam. These include intermediate goods explicitly, and further decompose production into activity and commodity accounts. While there is a little more detail in this table as compared to Table 1, it still represents a double entry accounting version of classical macro accounts. Table 3 is a version of Table 2, calibrated to 2000 Vietnam data available from the General Statistical Office (GSO, 2001a, 2000b). The former reference is a document summarizing official macroeconomic data organized according to the UN System for National Accounts (SNA) for the 1990-2000 period. These National Income and Product Accounts (NIPA) were up-dated by the GSO under a consultancy contract, available in the latter GSO paper.

[Tables 1, 2, 3 about here]

In sum, Table 3 provides an up-to-date macroeconomic data set for the Vietnamese economy, which is not only well documented, but also internally consistent. ${ }^{5}$ The way to read Table 3 is to use the labels from Table 2 alongside the data depicted in Table 3. For example, GDP at market prices can be found by deducting Imports (cell 8,2) from the sum of Private Consumption (cell 2,4), State Consumption (cell 2,6), Investment (cell 2,7) and Exports (cell 2,8). Note that this is equivalent to the sum of Value Added (cell 3,1) plus taxes in cells $(6,1)$ and $(6,2)$. Finally, column totals equal row totals by construction.

To allow for more detailed policy experiments and establish the basis for a CGE model, the MacroSAM must be disaggregated. This is also required to establish

\footnotetext{
${ }^{4}$ See Reinert and Roland-Holst (1997) for a more extensive introduction to MacroSAMs and SAM estimation.

${ }^{5}$ For further detail, see Tarp, Roland-Holst, Rand, and Jensen (2002).
} 
the structure of supply and demand as well as value added and the distribution of factor incomes in focus in the present paper. We therefore disaggregated the MacroSAM into a matrix with dimensions $318 \times 318$. This reflects, first of all, that the detailed SAM includes 97 production activities with 97 counterpart commodities (including eight agricultural sectors, two agricultural service sectors, and 13 food processing sectors, commensurate with the importance of agricultural activities to the Vietnamese economy). In addition, there are: 14 factors, 16 household types, three enterprises, one state account, one investment/savings account, and 89 accounts related to trade and foreign capital flows.

Factors include twelve types of labor, one aggregate capital factor and one aggregate land factor. Labor is disaggregated in three dimensions: rural-urban, gender and educational level. Household disaggregation takes account of the rural-urban, male-female and wage/farm/self/non-employed dimensions. Enterprises include state, private (non-state) and foreign-invested companies. Some 88 trading partners are also identified.

The primary data sources allowing the above disaggregation include, first, a 1996 I/O table (GSO, 1999). This table was developed in accordance with international I/O standards and it provides the most detailed and accurate picture of the input-output production structure of the Vietnamese economy available at present. Second, we relied extensively on the 1997-98 VLSS household survey (GSO, 2000). This directly sampled, nationally representative, household survey included some 6000 households in accordance with World Bank LSMS (Living Standard Measurement Survey) principles. ${ }^{6}$ Third, for trade accounts in the 2000 SAM we used data from the COMTRADE international trade database (United Nations Statistical Office, 2001). This database is maintained by the United Nations Statistical Office and contains detailed commodity by partner trade data for approximately 100 countries for each year from 1962 onwards. COMTRADE keeps country-by-country merchandise trade data with very detailed product categories and complete detail on originating county for imports as well as destination of exports. Unfortunately, Vietnam does not report to COMTRADE at the present time, so it was necessary to sample Vietnamese trade flows by indirect means. This meant sampling all reporting countries (over $90 \%$ of global trade) for their exports to and imports from Vietnam. Practically speaking, we obtained import and export flows, to and from Vietnam, for the partner countries and over 9,000 merchandise customs lines, for a four-year period. We therefore had to aggregate these customs lines to the 97 sectors (only 68 of which are commodities) in the SAM before estimating the trade and service flows (as

\footnotetext{
6 See the World Bank web-site (www.worldbank.org/lsms/) for further background and the data set used.
} 
described in detail in Tarp et al. 2002). This was a very data intensive process, but we believe it represents an accurate picture of foreign trade of Vietnam.

To complete the SAM estimation procedure, it was necessary to reconcile the data sources mentioned above into one consistent economy-wide set of tabular accounts. This was done using a matrix-balancing algorithm developed by Sherman Robinson and a variety of co-authors, see e.g., Robinson et al., 1998 and Robinson and El-Said (2000). This technique, referred to as Cross Entropy Estimation, permits the estimation of detailed accounts that are consistent with exogenously specified accounting constraints. Finally, it should be noted that judgment was necessary at various points in the SAM estimation procedure, but we also note that SAM estimation, like all production of economic statistics, is a continuing process subject to revision and improvement.

While detailed economic structure is in focus in this paper, we nevertheless chose to aggregate the 97 activity and commodity categories in the 2000 SAM into 30, and the 88 trading partners were aggregated into 14 regions. 7 This sector aggregation was pursued to reflect the diversity of the economy at a reasonably detailed level, whereas the geographic aggregation captures the major trading partners and regions facing Vietnam.

\section{Supply, Demand, Value Added and Factor Income}

Table 4 presents a variety of disaggregated economic statistics extracted from the SAM. ${ }^{8}$ In column 1 , for example, shares of economy-wide gross output are given for all 30 sectors and aggregates representing primary, industry, and service activities. As one would expect for an economy at Vietnam's stage of development, most of output is concentrated in primary and secondary activities. Even these statistics understate the importance of the rural and food sector, which provides employment to over twothirds of the population, because of the large subsistence or non-market component of agricultural output (see also Bales, 2000).

[Table 4 about here]

There are - as will be revealed in this section - many indications that Vietnam's agricultural potential could be expanded significantly and sustainably.

\footnotetext{
${ }^{7}$ The aggregated 30 -sector SAM is available from the authors on request.

8 The sector classification used in the following tables is based on a distinction among primary, secondary and tertiary sectors that is different from the classification used by the GSO (1999). For example, GSO classifies Mining as a secondary sector of production together with Industry.
} 
Ideally this would be done in ways that respond to more attractive output prices and greater value-added capture. In terms of the former, this would mean shifting the composition of crops toward higher value varieties. More domestic food processing capacity could also be developed, independently or in foreign partnership, and preferably located in rural regions where the income gains would be most significant.

More detailed inspection of the SAM also reveals that over half of gross output is in primary and light industry sectors, with the highly capital intensive-type industry accounting for less than $8 \%$ of total output. Primarily because of capital insufficiency, Vietnamese industry is only beginning the path to modernization and manufacturing diversification commensurate with its population size and resource base. For this reason, processed food, construction materials, and labor-intensive light industries dominate its secondary sector.

Excluding the construction sector, only about one third of Vietnam's gross output takes the form of marketable services. Service output, employment, and value added are the hallmarks of developed countries, the average in the OECD exceeding $65 \%$ (see for example WDI, 2001), and Vietnam is clearly only beginning to develop this component of economic activity. As development takes place and incomes and rural-urban migration rise over time, however, the share of services in overall output can be expected to grow substantially in line with the underlying structural transformation of the economy.

The second column of Table 4 gives sector shares of domestic supply, i.e. domestic output delivered to the domestic market. Generally, the differences between these and the gross output shares are better understood by reference to Column 3, which gives the corresponding export shares, a measure of supply-side trade dependence for each sector. Despite its heavy reliance on primary sector activities, Vietnamese exports are already more concentrated in sectors classified as industrial (43.35\% against $30.42 \%$ ). The main reason for this is the Textile and Apparel sector, which accounts for $16.36 \%$ of total exports in 2000 . This closely reflects government trade and industrial policy as pursued under doi moi. Changes in trade policy, including for example the lifting of export quotas and removal of export taxes, have been an essential element of the doi moi reform policy pursued by the Vietnamese government, and it certainly appears that this is now paying off as Vietnam is entering the $21^{\text {st }}$ century (World Bank, 2000).

More detailed examination of these shares also reveals many opportunities for Vietnamese development. For example, food and non-food crops, such as rice and coffee, have significant export shares already (reflecting decisive government policy measures taken during the 1990s). Nevertheless, they are generally thought to be producing below their long-term revenue potential (Lindahl, 2001). Likewise, the Oil 
and Gas sector has a significant share of 2000 exports, but is only beginning to develop its long term potential by overcoming capital constraints as a result of government policy to promote foreign direct investment.

Manufacturing has been at the core of the Vietnamese development strategy as reflected in government's investment priorities over the years (see World Bank, 2001). However, even a cursory review of column 3 indicates that Vietnam has not yet captured the export potential of dynamic growth sectors elsewhere in ASEAN, including technology, consumer durables, and even vehicles (see United Nations Statistical Office, 2001, and WDI, 2001). These sectors not only leverage external demand for domestic employment and capacity development. They are also capable of accelerating modernization and confer many growth externalities on the domestic economy. In other economies of the region, the primary catalysts for development of these sectors were foreign capital and sustained state commitments to human capital development via education and labor market liberalization as discussed in Stiglitz and Yusuf (2001).

A more focused comparison between production for domestic and external markets can be made with the ratios given in the fourth column of Table 4. Here the export orientation of certain sectors, such as cash crops and energy, promoted throughout the 1990s (see IMF, 2002), comes into relief. Several agricultural sectors, including rice and fishery, are still directing the vast majority of their output to domestic markets, while their export potential at the margin is beginning to be realized as illustrated in Nghiem and Coelli (2000), who provide insights into the impact of incentive reforms on the Vietnamese rice sector. Given that rice is an inferior good, its export potential at the margin of a growing economy is considerable. Conversely, fishery supply may increasingly be diverted to the domestic market as Vietnamese per capita incomes rise. In the latter case, export shares will depend heavily on capacity expansion in aquaculture. Marine fisheries in the region are being exploited near or even beyond sustainable capacity. Significantly, export ratios for food processing are also very low, indicating that the export potential of the Vietnamese agricultural sector, apart from classical cash crops like coffee and rubber, is far from being realized. Thus, unless progress can be made in this area, rural incomes are unlikely to keep pace with growth of the overall economy.

The challenge facing Vietnam in an era of globalization can be clearly seen in the average export ratio for industry, which indicates an economy with very low levels of external supply orientation in the growth inducing sectors that have accelerated development and living standards elsewhere in Asia (see United Nations Statistical Office, 2001). Without more external market linkage in a variety of essential industrial activities, Vietnam is likely to be a chronic underachiever in the 
Asian modernization process that began with Japan and has continued to spread around the region. Again main reasons are capital insufficiency and lack of access to technology, but institutional conditions can do much to overcome this, facilitating commercial and multilateral trade partnerships to leverage Vietnam's rich human and natural resource base. ${ }^{9}$

Service sector export ratios are also very low. While it would be nice to see higher levels in externally oriented sectors like transportation and hotels/restaurants, low service exports are typical of all but the most advanced economies (see for example WDI, 2001). Related to services, Vietnam has over the past couple of decades done much to improve existing infrastructure and promote a level playing field among the private and state sectors. It emerges, however, that this is yet to have any significant impact on service exports (see also World Bank, 2000).

Demand patterns for Vietnam are captured in columns 5-9, and they reflect characteristics typical of economies at this stage of development (see for example Chenery, 1979). Average incomes are quite low, and private consumption is concentrated on raw and processed food products, constituting about half of demand in this country. The remaining half is divided about equally between manufactures and services, although the figure of $9.54 \%$ may include non-discretionary contributions for obligatory public services. Urban households have recently increased demand for durables, reflecting increased income, but on a national basis, Vietnamese households have very limited means for discretionary consumption. This is particularly true of the more than three quarters of the population residing in the rural sector. For this reason, the internal market cannot be expected to animate or sustain rapid investment in growth-oriented sectors such as consumer durables or household/business/personal technology. These forces will only come into play after significant gains in domestic per capita income. Again these facts support the case for greater external orientation in investment and industrial policy than was experienced during the past couple of decades (see Hakkala, Kang, and Kokko, 2001, who discuss the previous import substituting strategy at length).

Vietnamese investment patterns in 2000 also reflect those of an agrarian developing country. Table 4 documents that about two thirds of capital outlays in Vietnam are concentrated in the construction sector. The second largest type of investment demand, the aggregate Other Machinery sector, gives an indication of where capital goods spending can be expected to shift in the coming decades, in line with government policy to promote an expansion and diversification of the economy. However, as the economy is being modernized, one would in fact expect to see investment demand increasing sharply in most of the non-food industrial activities,

\footnotetext{
${ }^{9}$ See World Bank (2001) for further discussion on this.
} 
particularly those that are technology and infrastructure related. Infrastructure and science and technology for industrialization, modernization and knowledge-based development is very much in focus in the government's strategy for socio-economic development during the 2001-2010 period (see Communist Party of Vietnam, 2001 and World Bank, 2001).

Columns 7-9 describe demand patterns by origin of goods and services consumed. Here we see significant disparities between domestic and imported expenditure shares, largely a result of the undeveloped characteristics of the Vietnamese economy. Most food demand is met by domestic sources, while fully $81.45 \%$ of imports are manufactured goods for which there is little or no domestic substitute. ${ }^{10}$ The largest component of domestic Service demand is for a non-tradable, Construction. Column 9 gives ratios of relative import dependence that are analogous to the export ratios in column 4 . These tell a similar story to the observations of the paragraph above, but more strikingly. The average import ratio for Primary products is only 0.18 , while that for Industry is 1.04. This underscores that Vietnam is as an emergent economy, still heavily reliant on imported technology and vulnerable to shocks in the global terms of trade. In the past, developing countries, including Vietnam, attempted to reduce these risks with inward oriented import substitution strategies. ${ }^{11}$ Today, it is generally acknowledged that imports are better displaced by domestic capacity developed from greater participation in external product and capital markets.

The sector information in columns 10-14 of Table 4 leads us into discussion of Vietnamese income determination, detailing value added shares for labor, capital and land across the 30 activities. Some $35 \%$ of total value added arises in primary activities, whereas services contribute $46.29 \%$. Industry accounts for only $18.39 \%$ (and $11.13 \%$ when food processing is excluded). Land value added is naturally concentrated in the primary sector.

Among primary sectors, it comes as no surprise that rice production predominates in value added, followed closely by other subsistence sectors. Rice is at the backbone of the Vietnamese economy, and government policy during the doi moi reforms has undoubtedly had a major impact on the improved performance of this sector (IMF, 2002). Oil and Gas has a large share of primary value added, but most of this goes to capital (column 12). Leaders in industry are processed foods, materials (this via downstream links to Construction), and Textile/Apparel. Among Services, the largest source of value added is Commercial Services and Trade. This is mainly

\footnotetext{
10 At very detailed customs lines, one observes very little intra-industry trade in Vietnam for the same reason. This is symptomatic of low levels of domestic product diversification.

${ }^{11}$ For a general overview see, for example, Gillis, Perkins, Roemer, and Snodgrass (1996), and Vietnam specific background is provided by Hakkala, Kang, and Kokko (2001).
} 
made up of small-scale operators capturing trade and transport margins in retail distribution channels. This undoubtedly reflects in large measure the government's policy to liberalize and promote private small and medium scale enterprises (World Bank, 2001).

It was observed earlier that OECD countries also generate the largest share of value added in Service activities, but this happened only after their transition through an industrial phase, where manufacturing became the dominant source of employment and factor income (Chenery, 1979). Vietnamese services are relatively simple distribution activities and have neither the technological sophistication nor the skillintensity of advanced economy professional services. Thus, as development proceeds in the coming decades one can expect that Vietnam will undergo a three stage transition, accompanied by significant rural-urban demographic change: 1) the present stage, where agriculture and petty commerce continue to dominate value added; 2) industrialization and significant new urbanization; 3) modernization, with higher domestic incomes and a large, diversified internal market with a dominant, modern service sector.

Looking at value added by factor type, we see that over one quarter of Vietnam's labor income arises from rice production (Rice) and petty commerce (Trade). As can be expected in a country with relatively low levels of mechanization, labor value added is high in most agricultural sectors, and about $82 \%$ of Vietnam's labor value added continue to accrue to primary and service sector employment. This reflects that while total production has gone up in line with economic reforms, much remains to be achieved in expanding productive capacity in the agricultural sector with pay off in terms of increased productivity, gains in output, rising prosperity for rural people, and increased export revenues (World Bank, 2001). Raising the level of investment, which remained well below that of China during the 1990s, is clearly a key challenge for Vietnam in the coming decade. Reforming the financial sector has been initiated but needs to be vigorously pursued.

To get a clearer impression of the relative rewards to different factors engaged in different activities, consider the labor to capital value added ratios in column 14. Here the labor intensity of certain activities is obvious, like Rice, Other Crops, Livestock, and Forestry. By contrast, Raw Rubber, Oil and Gas, Beverage/Tobacco, and Manufactured Materials are much more capital intensive. Large disparities in factor intensity are also evident in Services, where Public Services are about 17 times more labor intensive than Commercial Services. All these differences imply that the employment and distributional implications of industry policy need careful forethought. Sectors that are targeted for expansion, whether to serve domestic or external markets can have very different effects on domestic factor use and relative 
incomes, and these effects will ultimately have political as well as economic consequences. The Vietnamese government is clearly well aware that employment implications of developments during the past years leave much to be desired. Promoting employment intensive growth is for good reasons one of the core elements of the development strategy for the period 2001-2010.

Patterns of Factor ownership and relative returns to those factors are of course the primary determinants of both absolute and relative incomes. This is true in a market or planned economy, or indeed any economy that attempts to combine the two types of organization, as is the case in Vietnam. While Vietnam is in a transition to a mixed economy, the labor intensity of most of its production activities means that labor compensation is the principal determinant of private domestic incomes. Because of its disaggregated treatment of both the sources of employment and occupational categories, the Vietnam SAM provides very detailed information on the functional distribution of income, which should facilitate its use in economic analysis and policy formulation.

Table 5 displays the composition of direct income (value added) accruing to each of the factors in the 2000 SAM (including twelve labor categories, capital, and land as noted in Section 2). Data are represented here as percent shares of one Dong of value added in each of the 30 sectors. Thus, these figures sum to $100 \%$ across each row, and value added weighted averages are given for each of the three generic activity categories: Primary, Industry, and Services.

[Table 5 about here]

In primary sectors, the majority of value added accrues to unskilled labor, totaling 56.26\% when Rural (columns 1,4) and Urban (columns 7, 10) workers are combined. Excluding energy and mining sectors, returns to Primary unskilled labor (columns $1,4,7,10$ ) are over two-thirds of total Primary value added. Returns to capital in Primary activities (column 13) vary tremendously, from a low of $3.93 \%$ in Rice to $60.86 \%$ in Oil and Gas. Land (column 14) is only accounted as a factor in seven primary activities, and its share of value added varies considerably.

Patterns of ownership in agriculture also differ sharply between subsistence and cash crops, where relative returns to capital (column 13) in Rubber, Coffee, and Other Agriculture are over three times those in Rice, Other (food) Crops, and Livestock. This dichotomy reflects two main tendencies. Firstly, low levels of mechanization exist in basic food production because of capital insufficiency and absence of scale economies. As already alluded to, increasing the level of investment 
(in rural areas) is a key challenge. Second, state owned enterprises (SOEs) in the agricultural export sectors have, as is clear from the SAM, succeeded in expanding exports very considerably, but they have not substantially transformed the plantation system in terms of consolidated property ownership, technology, and factor use. Moreover, the SOEs have not been associated with high levels of efficiency. This reduces final income to the owners of capital, be they public or private. In spite of reform efforts during the doi moi, SOE restructuring continues to be an essential need for growth and development to maintain their momentum.

Fishery, by contrast, has developed and expanded its export potential with over $85 \%$ of value added still accruing to labor (columns 1-12). More appropriate technology choice and extension programs could increase cash crop labor value added and external market access for small holders. Private, smallholder promotion remains an essential component of agricultural reform and sustainable rural development, as stated in Vietnam's socio-economic development strategy for the present decade.

Value added composition is more homogeneous across industrial sectors in Vietnam, with average shares for skill categories a little more uniform and higher shares for capital (in column 13, averaging 31.13\%). Unskilled labor as a group (columns 1, 4, 7, 10) receives little under half of value added on average. Both Rural (columns 4, 5, 6) and Urban female (columns 10, 11, 12) workers receive larger shares in Industrial than in Primary employment.

Important differences are still readily apparent, particularly in value added accruing to capital (column 13). Nearly half of all value added accrues to capital in the Beverage/Tobacco and Manufactured Materials sectors, and this is consistent with high levels of mechanization.

A lower level of capital share in value added is a double-edged sword for economic modernization in Vietnam. While it is desirable that labor receives significant compensation, returns to capital are indicators of both the incentive and the progress toward higher levels of technology and, ultimately, labor productivity. If Vietnam succeeds in attracting the capital needed to transform its manufacturing base, it is reasonable to expect that capital value added shares will rise steadily for a decade or two before falling again. Of course, these relative gains for capital will be accompanied by absolute increases in labor value added as economic growth accelerates.

A final point worth noting about the Industry results is the very low share of value added accruing to Highly Skilled Labor, less than 5\% for the combined averages of columns 3,6, 9, and 12. Much has been done in the education and knowledge sector, but these shares clearly reflect the scarcity of skilled labor in Vietnam. They also reflect the stage of industrialization and capitalization arguments 
of the preceding paragraph, but it is evident that Vietnam must reinforce activities to enhance human capacity and the quality of education to more fully realize its economic potential (World Bank, 2001). A reformed market economy can facilitate this process by pairing technology with labor in ways that accelerate the growth of the skill base, steadily increasing labor productivity and, ultimately, wages. For a poor country with limited means of financing higher education, this is an essential consideration for economic growth policy.

Value added composition within Service sectors is quite diverse, and the averages in this group are not particularly illuminating. This is because services are produced and delivered with very diverse technologies. Electricity, Gas and Water and Commercial Services both have high capital shares, but for different reasons. The former is a classical, big machine capital-intensive activity, while the latter is small machine, technology intensive. Personal and Public Services, by contrast, both give over $80 \%$ of value added to labor, skill composition varies somewhat between these sectors, but both are very labor intensive.

\section{Vietnam's Trade Patterns}

Because the 2000 SAM contains very detailed data on Vietnamese imports and exports, it can be used to elucidate and evaluate existing trade patterns, and identify trade opportunities facing the country. Tables 6-9 give share calculations, by activity and trading partner, for the 30-sector SAM and 14 aggregate individual and aggregate trading partners. Because of limitations in the indirect sampling approach we were forced to use, these trade patterns are approximate. Nevertheless, they provide a wide spectrum of very serviceable indicators on the directions and significance of Vietnamese trade. In what follows, we focus on a variety of economic factors behind these patterns. However, historical and political ties and relationships are certainly also reflected in the direction of Vietnamese trade and their importance should be fully recognized. A case in point is the low trade shares with the USA, which reflect past policy that discriminated against Vietnam. It is hoped that this discrimination will be phased out following the signing of the bilateral trade agreement (BTA).

Export flows are covered in Tables 6 and 7, with the former depicting percent shares of Vietnamese exports across destinations for each activity (i.e. rows sum to 100). Consider Rice, for example. In 2000, more than two thirds (68\%) of Vietnamese Rice exports were directed to ASEAN members. This figure is startling because it reveals how limited is the market diversification of one of the world's most important Rice producers. Two considerations in particular should be taken into account with these results in mind. First, while production has increased markedly, Vietnam will have to improve its Rice product quality and marketing before the potential of the rest 
of the world market can be exploited. Thus, while Vietnam and government policy has succeeded in changing the country from an importer to a large exporter of rice over the past two decades, much remains to be done in terms of economic efficiency as well as global market penetration. Second, in particular, Vietnam has not really begun to take advantage of export opportunities that will arise with its northern neighbor China, the world's largest rice consumer. Together with Other Asia, they represent more than half of world rice consumption and their supply capacity is severely taxed (as discussed by Yang, 1999). Yet, the 2000 SAM shows that exports from Vietnam are negligible or non-existent at present.

[Tables 6, 7 about here]

A similar argument holds for Coffee and the USA. As of 2000, the EU bought over half Vietnam's crop but the world's largest consumer buys only about a third as much. Many other coffee importing countries have negligible export shares. This pattern is repeated in a variety of Primary sectors, including food, forestry, fishery, and energy. In all cases, Vietnam's global market access appears quite restricted. In all likelihood, this results from a combination of insufficient marketing and incomplete trade negotiations plus the historical and political factors alluded to above. When the majority of exports are going to only two or three trading partners, however, the result is limited competition and, in all likelihood, relatively unfavorable terms of trade. Vietnam clearly needs to expand both its export marketing and trade negotiating capacity in follow-up to the standard trade liberalization measures taken so far during doi moi.

A similar situation prevails in Industry, but not quite as much segmentation is apparent. It is natural that Vietnam should be fixed into the supply chain of its foreign venture partners, like Japan, Taiwan, Hong Kong, and ASEAN. At the same time, however, large shares for sector exports to the EU imply that market opportunities for final goods (and hence higher value added) exist in OECD countries. Here is where accelerated liberalization with respect to the North American Free Trade Agreement (NAFTA) could be very beneficial to Vietnam. It would clearly be preferable for Vietnam to become a final goods export platform rather than a supplier of intermediate components to other ASEAN exporters.

The entries in Table 7 give a different perspective on Vietnam's exports, listing shares of each type of good or service in total exports to each trading partner. For example, $15 \%$ of all Vietnamese exports to Hong Kong took the form of Livestock (row 5, column 5). A quick glance at the last column reveals total export 
composition across activities, with $33 \%$ Primary products, $42 \%$ Industrial goods, and $25 \%$ Services (mainly commercial intermediation).

Beyond this, it is apparent that many trading partners demand Vietnam's main exports, including Textile/Apparel and Energy. Textile/Apparel goods are very prominent among exports to Taiwan, Korea, and Hong Kong, probably as intermediate deliveries to their large apparel sectors, while Canada is more likely a final consumer. If Vietnam can continue to attract greater overseas financial partnership, through its policy of foreign direct investment, which has been relatively successful during the 1990s, Vietnam can move up the value added ladder, divert intermediate textile exports to a domestic apparel sector, and export more finished goods to OECD countries. This process could be accomplished by negotiated capacity shifting from the intermediate export destinations like Taiwan, Korea, and Hong Kong.

Perhaps the most arresting feature of these export shares is the lack of diversity they reveal. This trade table is rather sparse (many zeroes), and about half the possible trade linkages between Vietnam and the rest of the world, partitioned into only 14 groups and 30 products, are negligible or non-existent. Among the small number of remaining products and partners, trade is highly concentrated. This means that many external market opportunities are eluding this resource rich economy, and that its production structure lacks the diversification necessary to participate more fully in the process of globalization. WTO accession is underway and could no doubt help in this regard (see Anderson, 1998 for an overview of the arguments involved).

Data in Tables 8 and 9 tell the story of Vietnam's trade patterns from the import side. Looking at imports by activity, in percentage shares by country of origin, it is clear that geographic patterns differ significantly from exports. Several rows are not of great importance in the 2000 data so imports in these categories were negligible. They include most Primary products, which together constitute only 5.2\% of Vietnam's 2000 imports (see Table 4). Among those Primary goods that are imported, however, it is interesting to see China emerge as a prominent country of origin, consistent with the stated government aim of integrating Vietnam in the region, but nevertheless a cause of much concern in Vietnam. Partners with significant agricultural subsidy programs, like the EU, ANZ, Canada, and the US are also significant sources of food crops. It is beyond the scope of this paper to assess how likely it is that subsidized food imports from Western countries will continue, but it does indicate that Vietnam is for the time being increasingly being drawn into international food markets as an importer of for example livestock.

[Tables 8, 9 about here] 
Of greater significance are Industrial goods, where most of Vietnam's import demand is concentrated. Here ASEAN is a consistently important trading partner, but we again see China in a more prominent role than it held as an export destination, illustrating the need to develop Vietnam's competitive position vis-à-vis China. Otherwise, Vietnamese dependence on more technologically advanced countries, like Taiwan and the EU, is exactly what might be expected for its stage of development. It also reflects the policy of relatively low tariffs on the imports of this kind of goods, which are meant to further industrialization and modernization (see CIEM, 2001).

Service imports to Vietnam are made up primarily of trade and transport margins (see again Table 4), and thus are distributed according to origin of other imports.

Import shares by activity, for each trading partner, are given in Table 9. These bear out the manufacturing import dependence alluded to earlier. Consistently, the largest shares of imports are in Chemicals, Technical Manufactures, and Other Machinery, all areas where an agrarian economy pursuing economic transformation could be expected to be import dependent. On the other hand, these are key sectors in modern Asian industrialization (Dutta, 1988). Service imports are a relatively constant share of imports by country of origin, fluctuating around the average of $10 \%$.

This concludes the review of the 2000 Vietnam SAM database. In this overview of the table, many digressions were made to illustrate the scope for policy interpretation that arises from direct inspection of the database and the way in which the details of the SAM can be used to evaluate the impact of government policies.

\section{Conclusions}

SAMs are most intensively used in complex multiplier and policy simulation models. As demonstrated in this paper, however, much can be learned from direct inspection of the SAM. This overview of a 30-sector aggregation of the 2000 Vietnam SAM demonstrates a number of key characteristics of the economy and identifies development challenges for Vietnamese policymakers, illustrating the strength of the SAM as an analytical tool. Among the many structural characteristics noted above, some are worthy of special emphasis:

- The economy of Vietnam relies heavily on primary sector activities. However, there are many indications that Vietnam's agricultural potential could be expanded significantly. Ideally, this would be done in ways that capture greater value-added, shifting the composition of crops toward higher value varieties in accordance with existing policy guidelines. 
- Vietnamese exports are concentrated in sectors classified as industrial, with particular reliance on textiles and apparel, while several agricultural sectors, such as rice and fishery, are still directing the vast majority of their output to the domestic market. The export potential of the latter is only beginning to be realized, and this also seems to be the case for food processing (excepting coffee and rubber) and the oil and gas sector. The export potential of rice appears significant, especially if quality improves, while fishery supply could continue to be diverted towards the domestic market as demand increases with rising incomes. When it comes to trading partners, data clearly reveal the still rather limited diversification of Vietnam's global market penetration.

- In manufacturing, Vietnam is also far from realizing the potential of dynamic growth sectors such as technology and consumer durables. For this to happen, the importance of foreign capital and sustained commitments to human capital development via education and labor market reform need to be more substantively recognized than in the past.

- Average incomes remain quite low in Vietnam. The capacity of internal market demand to generate adequate and sustained savings for investment in growth oriented sectors such as consumer durables and technology is likely to remain limited for quite some time. Particular attention should therefore be paid to ensuring international competitiveness and promoting external partnership for these sectors, including the promotion of foreign direct investment, as stated in a variety of government policy guidelines.

- At present, investment is heavily concentrated in construction. In a mediumterm growth scenario, one would expect to see investment demand increase more rapidly in sectors that are technology and infrastructure related. This highlights once more the importance of both financial and human capital, which in turn is likely to have implications for external financial policy and domestic policy towards education and labor markets.

- Vietnam is an agrarian economy in a process of transformation. As such, it is heavily reliant on imported technology and vulnerable to adverse changes in the international terms of trade. The issue of how to invest for production that meets both domestic and external demand seems important, highlighting the need to build efficient domestic capacity with the ability to compete in international markets.

- Significant differences exist in the labor to capital value added across sectors. This implies that the employment and distributional implications of development policy deserve careful consideration. Sectors targeted for 
expansion can have different effects on domestic factor use and relative factor incomes. In light of the important role of agriculture, smallholder promotion would appear to be an essential element of sustainable and equitable rural development.

Finally, it is obvious from our analysis that Vietnam's great economic promise cannot be fulfilled without a sustained commitment to realizing the enormous human potential of its relatively young and healthy population. For a country with limited means of financing higher education, it would be beneficial to identify more diverse approaches to the promotion and improvement of skills. For example, more extensive reforms of product, financial, and labor markets are likely to make significant contributions here, facilitating the confluence of labor and technology in ways that might accelerate productivity growth and, ultimately, real wages and living standards. The international donor community can also help through concerted training and capacity building initiatives that have proven successful elsewhere in the region. 


\section{References}

Anderson, K. (1998), Vietnam's Transforming Economy and WTO Accession, University of Adelaide, Adelaide.

Bales, S. (2000), "Vietnam's Labor Situation and Trends: Analysis based on the 199293 and 1997-98 Vietnam Living Standards Survey," Background Paper for the Vietnam Development Report 2000, World Bank, Hanoi.

Bautista, R. (2000), “Agriculture-Based Development: A SAM Perspective on Central Viet Nam," TMD Discussion Paper No. 51, International Food Policy Research Institute (IFPRI), Washington, D.C.

Chenery, H.B., (1979), Structural Change and Development Policy, Johns Hopkins, Baltimore.

CIEM (2001), Vietnam's Economy in 2000, Statistical Publishing House, Hanoi.

Communist Party of Vietnam (2001), "Socio-Economic Development Strategy: 20012010", Document of the $9^{\text {th }}$ Nationwide Party Congress, National Political Publishing House, Hanoi.

Dutta, M. (ed.) (1988), Asian Industrialization: Changing Economic Structures, Research in Asian Economic Studies, Vol. 1, Part A, JAI Press, London.

Gillis, M., D.H. Perkins, M. Roemer, and D.R. Snodgrass (1996), "Economics of Development", Norton, New York.

GSO (1999), Input-Output Tables for Vietnam, General Statistics Office, Hanoi.

GSO (2000), Vietnam Living Standards Survey, General Statistics Office, Hanoi.

GSO (2001a), The System of National Accounts for Vietnam, General Statistics Office, Hanoi.

GSO (2001b), "Data for 2000 Provided to Supplement The System of National Accounts for Vietnam," Mimeo, General Statistics Office, Hanoi.

Hakkala, K., O. H. Kang, and A. Kokko (2001), "Step by Step: Economic Reform and Renovation in Vietnam before the $9^{\text {th }}$ Party Congress", Working Paper, Stockholm School of Economics.

Huong, L. (2000), "Impacts of Trade and Investment Policy on Income Distribution in Vietnam Using a General Equilibrium Framework," ANU thesis, Canberra.

IMF (2002), "Vietnam: Selected Issues and Statistical Appendix", IMF Country Report No. 02/5, Washington, DC. 
Le Dang Doanh (2000), "Development and Economic Reform in Viet Nam", UN News, Vol. 6, No. 2, The Quarterly Journal of the United Nations in Viet Nam.

Lindahl, C. (2001), "Initial Assessment of Export Potential of Vietnam”, VIE/98/021 project report, Hanoi.

Nghiem, H.S., and T. Coelli (2000), "The Effect of Incentive Reforms Upon Productivity: Evidence from the Vietnamese Rice Industry", Working Paper, University of New England, Armidale.

Pyatt, G. and J. Round (eds.) (1985), Social Accounting Matrices: A Basis for Planning, The World Bank, Washington, D.C.

Reinert, K.A., and D. Roland-Holst (1997), "Social Accounting Matrices," in J.F. Francois and K.A. Reinert (eds.), Applied Methods for Trade Policy Analysis, Cambridge: Cambridge University Press, 1997.

Stiglitz, J.E., and S. Yusuf (2001), Rethinking the East Asian Miracle, World Bank and Oxford University Press, New York.

Tarp, F., D. Roland-Holst, J. Rand, and H. T. Jensen (2002), "A Social accounting matrix for Vietnam for the year 2000: Documentation," CIEM/NIAS working paper, CIEM, Hanoi.

United Nations Statistical Office (2001), COMTRADE Bilateral Direction of Trade Statistics, United Nations, New York.

United Nations (undated), Social Accounting Matrix Based Macro Models for Policy Analysis in Developing Countries, United Nations, New York.

WDI (2001), "World Development Indicators, CD-Rom 2001", World Bank, Washington DC.

World Bank (2000), "Vietnam: Export Performance in 1999 and Beyond”, World Bank, Hanoi.

World Bank (2001), Vietnam 2010: Entering the $21^{\text {st }}$ Century, World Bank, Hanoi.

Yang, H. (1999), “Growth in China's Grain Production 1978-1997: A Disaggregate Analysis", World Development, Vol. 27, No. 12, pp. 2137-54. 
Table 1: An Open-Economy MacroSAM with a Government Sector

Expenditures

\begin{tabular}{|c|c|c|c|c|c|c|}
\hline Receipts & 1 & 2 & 3 & 4 & 5 & Total \\
\hline 1. Suppliers & - & $\mathrm{C}$ & G & I & $\mathrm{E}$ & Demand \\
\hline 2. Households & Y & - & - & - & - & Income \\
\hline 3. Government & - & $T$ & - & - & - & Receipts \\
\hline 4. Capital Accnt. & - & $\mathrm{S}_{\mathrm{h}}$ & $\mathrm{S}_{\mathrm{g}}$ & - & $\mathrm{S}_{\mathrm{f}}$ & Savings \\
\hline 5. Rest of World & $\mathrm{M}$ & - & - & - & - & Imports \\
\hline
\end{tabular}

Total

Supply Expenditure Expenditure Investment ROW

Additional Variables:

$\mathrm{t}_{42}=\mathrm{S}_{\mathrm{h}}=$ private savings

$\mathrm{t}_{32}=\mathrm{T}=$ tax payments

$\mathrm{t}_{43}=\mathrm{S}_{\mathrm{g}}=$ government savings

$\mathrm{t}_{15}=\mathrm{E}=$ exports

$\mathrm{t}_{45}=\mathrm{S}_{\mathrm{f}}=$ foreign savings

$\mathrm{t}_{51}=\mathrm{M}=$ imports

$\mathrm{t}_{13}=\mathrm{G}=$ government spending

Accounting Identities:

1. $\mathrm{Y}+\mathrm{M}=\mathrm{C}+\mathrm{G}+\mathrm{I}+\mathrm{E} \quad$ (GNP)

2. $\mathrm{C}+\mathrm{T}+\mathrm{S}_{\mathrm{h}}=\mathrm{Y} \quad$ (Income)

3. $\mathrm{G}+\mathrm{S}_{\mathrm{g}}=\mathrm{T} \quad$ (Govt. Budget)

4. $\mathrm{I}=\mathrm{S}_{\mathrm{h}}+\mathrm{S}_{\mathrm{g}}+\mathrm{S}_{\mathrm{f}} \quad$ (Saving-Investment)

5. $\mathrm{E}+\mathrm{S}_{\mathrm{f}}=\mathrm{M} \quad$ (Trade Balance) 
Table 2: A Macroeconomic SAM for Vietnam - Generic Macro Accounts

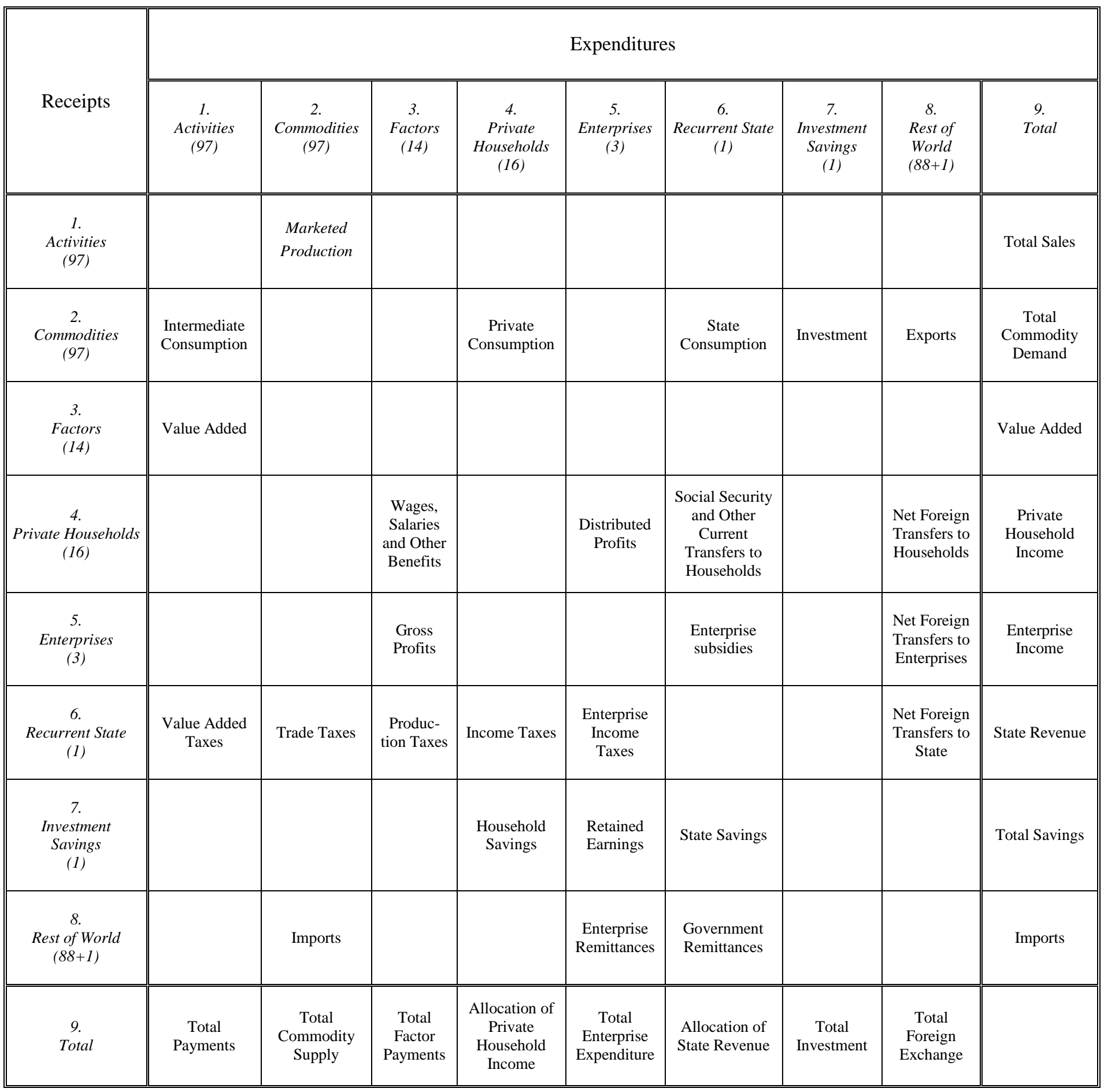


Table 3: Macroeconomic SAM for Vietnam 2000

\begin{tabular}{|c|c|c|c|c|c|c|c|c|c|}
\hline \multirow{2}{*}{$\begin{array}{c}\text { Receipts } \\
\text { (Bill. VND) }\end{array}$} & \multicolumn{9}{|c|}{ Expenditures (Bill. VND) } \\
\hline & $\begin{array}{c}1 . \\
\text { Activities } \\
\text { (97) }\end{array}$ & $\begin{array}{c}2 . \\
\text { Commodities } \\
\text { (97) }\end{array}$ & $\begin{array}{l}3 . \\
\text { Factors } \\
\text { (14) }\end{array}$ & $\begin{array}{c}4 . \\
\text { Private } \\
\text { Households } \\
\text { (16) }\end{array}$ & $\begin{array}{c}5 . \\
\text { Enterprises } \\
\text { (3) }\end{array}$ & $\begin{array}{c}6 . \\
\text { Recurrent } \\
\text { State } \\
\text { (1) }\end{array}$ & $\begin{array}{l}7 . \\
\text { Investment } \\
\text { Savings } \\
\text { (1) }\end{array}$ & $\begin{array}{c}8 . \\
\text { Rest of } \\
\text { World } \\
(88+1)\end{array}$ & $\begin{array}{c}9 . \\
\text { Total }\end{array}$ \\
\hline $\begin{array}{c}1 . \\
\text { Activities } \\
\text { (97) }\end{array}$ & & 852,755 & & & & & & & 852,755 \\
\hline $\begin{array}{c}2 . \\
\text { Commodities } \\
\text { (97) }\end{array}$ & 427,323 & & & 295,993 & & 28,265 & 130,827 & 241,401 & $1,112,809$ \\
\hline $\begin{array}{l}3 . \\
\text { Factors } \\
\text { (14) }\end{array}$ & 376,376 & & & & & & & & 376,376 \\
\hline $\begin{array}{l}4 . \\
\text { Private Households } \\
\text { (16) }\end{array}$ & & & 270,487 & & 5,553 & 42,204 & & 19,842 & 338,086 \\
\hline $\begin{array}{c}5 . \\
\text { Enterprises } \\
\text { (3) }\end{array}$ & & & 105,636 & & & 6,245 & & 1,088 & 112,969 \\
\hline $\begin{array}{c}6 . \\
\text { Recurrent State } \\
\text { (1) }\end{array}$ & 49,056 & 19,307 & 253 & 1,840 & 25,033 & & & 2,072 & 97,561 \\
\hline $\begin{array}{l}7 . \\
\text { Investment } \\
\text { Savings } \\
\text { (1) }\end{array}$ & & & & 40,253 & 77,896 & 12,678 & & & 130,827 \\
\hline $\begin{array}{c}8 . \\
\text { Rest of World } \\
(88+1)\end{array}$ & & 251,747 & & & 4,487 & 8,169 & & & 264,403 \\
\hline $\begin{array}{c}9 . \\
\text { Total }\end{array}$ & 852,755 & $1,112,809$ & 376,376 & 338,086 & 112,969 & 97,561 & 130,827 & 264,403 & \\
\hline
\end{tabular}


Table 4: Structure of Supply Demand, and Value Added for Vietnam, 2000

Rice

Raw Rubber

Coffee Beans

Other Crop

Other Agriculture

Forestry

Fishery

Coal

Oil and Gas

Mining

All Primary

Meat and Dairy

Beverage and Tobacco

Seafood

Other Proc Food

Mfg Materials

Chemicals

Technical Mfg

Vehicles

Other Machinery

Textile and Apparel

Other Industry

Elec. Gas. Water

Construction

Trade

Transportation

Hotel and Restaurant

Personal Services

Commercial Services

Public Services

All Service

All Economy

\begin{tabular}{rrrrrrr}
1 & 2 & 3 & $4^{*}$ & 5 & 6 & 7 \\
$X$ & $S d$ & $E$ & $E / S d$ & $C$ & $I$ & $D d$ \\
\hline 6.98 & 6.60 & .71 & .03 & 1.93 & .84 & 4.65 \\
.24 & .03 & .88 & 8.44 & .00 & .00 & .15 \\
.71 & .03 & 2.59 & 21.62 & .00 & .00 & .47 \\
4.15 & 3.35 & 5.08 & .41 & 5.82 & .09 & 1.49 \\
3.24 & 2.83 & 1.18 & .11 & 7.15 & .69 & 3.08 \\
.46 & .45 & .00 & .00 & .00 & .00 & .51 \\
.95 & .98 & .09 & .03 & .54 & .02 & .39 \\
2.80 & 2.14 & 2.33 & .30 & 3.12 & .02 & 1.92 \\
1.02 & .41 & 2.14 & 1.41 & .19 & .33 & .74 \\
3.69 & .05 & 15.19 & 84.61 & .00 & .22 & .83 \\
1.73 & 1.71 & .22 & .04 & .00 & .02 & 2.43 \\
\hline 25.98 & 18.58 & 30.42 & 12.86 & 18.74 & 2.23 & 16.66
\end{tabular}

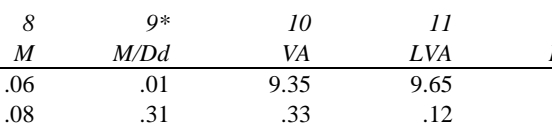

$\begin{array}{rrrr}.08 & .31 & .33 & .12 \\ .02 & .02 & .96 & .66\end{array}$

$\begin{array}{rrrr}.02 & .02 & .96 & .66 \\ .36 & .93 & 6.85 & 7.55\end{array}$

.05
.00

.28

$\begin{array}{rr}.00 & .42 \\ -43 & 1.55\end{array}$

\begin{tabular}{|c|c|c|c|c|c|c|c|c|c|c|c|c|c|}
\hline .60 & .74 & .22 & .08 & 1.36 & .15 & 8.84 & .72 & .51 & .35 & .39 & .33 & .00 & 2.78 \\
\hline 2.23 & 2.68 & .94 & .10 & 7.02 & .37 & 1.95 & 2.21 & .67 & 2.50 & 1.94 & 4.25 & .00 & 1.09 \\
\hline 1.82 & .43 & 4.95 & 3.15 & .34 & .01 & 2.21 & .03 & .01 & 1.45 & 1.77 & .93 & .00 & 4.57 \\
\hline 9.22 & 6.85 & 10.23 & .41 & 17.91 & .91 & 15.45 & 2.46 & .09 & 2.96 & 2.90 & 3.60 & .00 & 1.94 \\
\hline 5.83 & 5.79 & 4.82 & .23 & 1.77 & .91 & 8.05 & 4.34 & .32 & 3.59 & 2.71 & 6.28 & .00 & 1.03 \\
\hline 2.32 & 6.84 & 2.42 & .10 & 3.02 & 1.49 & 3.42 & 17.82 & 3.07 & 1.21 & 1.24 & 1.33 & .00 & 2.23 \\
\hline 1.03 & 4.82 & .49 & .03 & 6.95 & 7.66 & 1.52 & 13.15 & 5.10 & .54 & .55 & .60 & .00 & 2.19 \\
\hline 1.02 & 2.28 & 1.01 & .12 & 3.05 & 1.20 & 1.64 & 5.18 & 1.87 & .39 & .48 & .24 & .00 & 4.73 \\
\hline 1.13 & 6.53 & .19 & .01 & .57 & 14.57 & 1.37 & 18.18 & 7.79 & .89 & .91 & .98 & .00 & 2.23 \\
\hline 4.81 & 4.25 & 16.36 & 1.05 & 4.66 & 1.49 & 6.88 & 12.32 & 1.05 & 2.75 & 3.05 & 2.46 & .00 & 2.98 \\
\hline 2.35 & 3.32 & 1.72 & .14 & 3.10 & .77 & 2.92 & 5.03 & 1.01 & 1.78 & 1.82 & 1.97 & .00 & 2.21 \\
\hline 32.36 & 44.52 & 43.35 & .52 & 49.76 & 29.52 & 46.26 & 81.45 & 1.04 & 18.39 & 17.75 & 22.96 & .00 & 2.54 \\
\hline
\end{tabular}

\begin{tabular}{|c|c|c|c|c|c|c|c|c|c|c|c|c|c|}
\hline 2.25 & 2.20 & .00 & .00 & 1.06 & .00 & 1.68 & .09 & .03 & 2.82 & 1.31 & 6.90 & .00 & .46 \\
\hline 10.18 & 9.84 & .00 & .00 & .00 & 63.67 & 14.66 & .00 & .00 & 5.70 & 6.30 & 5.20 & .00 & 2.90 \\
\hline 8.47 & 5.94 & 8.22 & .38 & 4.13 & 4.13 & 4.15 & .00 & .00 & 12.76 & 13.46 & 13.21 & .00 & 2.44 \\
\hline 3.17 & 2.85 & 5.25 & .50 & 2.12 & .45 & 2.71 & 4.27 & .93 & 3.63 & 2.49 & 6.94 & .00 & .86 \\
\hline 3.00 & 2.14 & 5.72 & .73 & 4.80 & .00 & 2.86 & 2.80 & .58 & 3.11 & 3.05 & 3.78 & .00 & 1.93 \\
\hline 1.75 & 1.73 & 1.38 & .22 & 3.13 & .00 & .95 & 1.45 & .90 & 2.49 & 3.12 & 1.42 & .00 & 5.27 \\
\hline 6.10 & 5.78 & 4.32 & .20 & 6.72 & .00 & 4.58 & 3.75 & .48 & 7.64 & 4.72 & 15.92 & .00 & .71 \\
\hline 6.75 & 6.44 & 1.34 & .06 & 9.54 & .00 & 5.50 & .98 & .11 & 8.13 & 11.19 & 2.16 & .00 & 12.44 \\
\hline 41.67 & 36.90 & 26.23 & .22 & 31.51 & 68.25 & 37.09 & 13.35 & .21 & 46.29 & 45.64 & 55.53 & .00 & 3.38 \\
\hline 100.00 & 100.00 & 100.00 & 13.60 & 100.00 & 100.00 & 100.00 & 100.00 & 1.43 & 100.00 & 100.00 & 100.00 & 100.00 & 4.66 \\
\hline
\end{tabular}

Notes: All figures in percentages except as indicated. Figures in these columns are simple ratios with group-weighted averages. Abbreviations used are the following: $\mathrm{X}=$ output, $\mathrm{Sd}=$ supply for domestic market,

$\mathrm{E}=$ exports, $\mathrm{C}=$ consumption, $\mathrm{I}=$ investment, $\mathrm{Dd}=$ demand for domestically produced products, $\mathrm{M}=$ import, $\mathrm{VA}=$ value added, $\mathrm{LVA}=$ labor value added, $\mathrm{KVA}=$ capital value added, TVA = land value added. 
Table 5: Factor Income Distribution by Sector

Rice

Raw Rubber

Coffee Beans

Other Crops

Other Agricultur

Forestry

Fishery

Coal

Oil and Ga

Mining

Average Primary

Meat and Dairy

Beverage and Tobacco

Seafood

Other Proc Food

Mfg Materials

Technical Mfg

Vehicles

Other Machinery

Textile and Apparel

Other Industry

Average Industr

Elec. Gas. Water

Construction

Trade

Transportation

Hotel and Restaurant

Personal Services

Commercial Services

Public Services

Average Service

Average Economy

\begin{tabular}{|c|c|c|c|c|c|c|c|c|c|c|c|c|c|c|}
\hline 1 & 2 & 3 & 4 & 5 & 6 & 7 & 8 & 9 & 10 & 11 & 12 & 13 & 14 & \\
\hline$L 01 R M U$ & LO2RMM & LO3RMH & $L O 4 R F U$ & LO5RFM & LO6RFH & LOTUMU & LO8UMM & LO9UMH & LIOUFU & LIIUFM & LI2UFH & Capital & Land & Total \\
\hline 32.83 & 3.67 & 0.27 & 1.92 & 0.25 & 0.04 & 26.76 & 2.35 & 0.05 & 1.18 & 0.10 & 0.01 & 3.93 & 26.64 & 100.00 \\
\hline 12.82 & 2.08 & 0.00 & 0.00 & 0.00 & 0.00 & 8.97 & 0.00 & 0.32 & 0.00 & 0.00 & 0.00 & 44.61 & 31.20 & 100.00 \\
\hline 23.68 & 4.47 & 0.27 & 0.05 & 0.00 & 0.00 & 15.02 & 2.36 & 0.02 & 0.04 & 0.07 & 0.00 & 22.39 & 31.63 & 100.00 \\
\hline 26.53 & 4.85 & 0.46 & 8.74 & 0.31 & 0.40 & 21.71 & 2.97 & 0.09 & 7.65 & 0.39 & 0.02 & 4.36 & 21.53 & 100.00 \\
\hline 30.41 & 4.52 & 0.28 & 1.41 & 0.66 & 0.26 & 41.60 & 5.28 & 0.18 & 3.44 & 0.52 & 0.20 & 7.05 & 4.20 & 100.00 \\
\hline 49.49 & 6.92 & 0.06 & 2.47 & 0.53 & 0.01 & 15.28 & 1.24 & 0.02 & 0.21 & 0.03 & 0.00 & 23.73 & 0.00 & 100.00 \\
\hline 29.02 & 7.61 & 1.59 & 35.50 & 7.91 & 1.54 & 0.77 & 0.40 & 0.17 & 0.95 & 0.38 & 0.15 & 6.31 & 7.70 & 100.00 \\
\hline 29.62 & 7.77 & 1.62 & 36.23 & 8.07 & 1.57 & 0.79 & 0.41 & 0.17 & 0.97 & 0.39 & 0.16 & 11.72 & 0.52 & 100.00 \\
\hline 33.49 & 8.79 & 1.84 & 12.77 & 2.85 & 0.55 & 11.37 & 5.89 & 2.43 & 4.35 & 1.76 & 0.71 & 13.22 & 0.00 & 100.00 \\
\hline 15.11 & 3.96 & 0.83 & 5.76 & 1.28 & 0.25 & 5.13 & 2.66 & 1.10 & 1.96 & 0.79 & 0.32 & 60.86 & 0.00 & 100.00 \\
\hline 33.93 & 8.90 & 1.86 & 12.94 & 2.89 & 0.56 & 11.52 & 5.97 & 2.46 & 4.41 & 1.78 & 0.72 & 12.06 & 0.00 & 100.00 \\
\hline 28.81 & 5.78 & 0.83 & $\begin{array}{l}10.71 \\
\end{array}$ & 2.25 & 0.47 & 14.45 & 2.68 & 0.64 & 2.29 & 0.56 & 0.21 & 19.11 & 11.22 & 100.00 \\
\hline 15.24 & 4.01 & 0.84 & 19.46 & 4.35 & 0.85 & 7.70 & 3.99 & 1.65 & 9.86 & 3.99 & 1.60 & 26.47 & 0.00 & 100.00 \\
\hline 10.84 & 2.85 & 0.60 & 13.84 & 3.09 & 0.60 & 5.47 & 2.83 & 1.17 & 7.01 & 2.83 & 1.14 & 47.74 & 0.00 & 100.00 \\
\hline 17.01 & 4.47 & 0.93 & 21.73 & 4.84 & 0.94 & 8.59 & 4.45 & 1.84 & 11.01 & 4.45 & 1.78 & 17.96 & 0.00 & 100.00 \\
\hline 13.67 & 3.59 & 0.75 & 17.46 & 3.89 & 0.76 & 6.90 & 3.58 & 1.48 & 8.85 & 3.58 & 1.43 & 34.07 & 0.00 & 100.00 \\
\hline 15.49 & 4.07 & 0.85 & 9.58 & 2.14 & 0.42 & 6.77 & 3.51 & 1.45 & 4.20 & 1.70 & 0.68 & 49.16 & 0.00 & 100.00 \\
\hline 21.03 & 5.53 & 1.16 & 13.01 & 2.91 & 0.57 & 9.19 & 4.76 & 1.97 & 5.71 & 2.31 & 0.93 & 30.93 & 0.00 & 100.00 \\
\hline 7.41 & 1.95 & 0.41 & 4.18 & 0.93 & 0.18 & 20.48 & 10.61 & 4.38 & 11.58 & 4.68 & 1.88 & 31.32 & 0.00 & 100.00 \\
\hline 8.91 & 2.34 & 0.49 & 5.02 & 1.12 & 0.22 & 24.62 & 12.75 & 5.27 & 13.91 & 5.63 & 2.26 & 17.47 & 0.00 & 100.00 \\
\hline 18.20 & 4.78 & 1.00 & 11.17 & 2.49 & 0.49 & 11.55 & 5.98 & 2.47 & 6.93 & 2.80 & 1.13 & 31.00 & 0.00 & 100.00 \\
\hline 5.86 & 1.54 & 0.32 & 21.16 & 4.72 & 0.92 & 5.44 & 2.82 & 1.17 & 19.73 & 7.97 & 3.20 & 25.14 & 0.00 & 100.00 \\
\hline 20.98 & 5.51 & 1.15 & 12.97 & 2.90 & 0.56 & 9.17 & 4.75 & 1.96 & 5.69 & 2.30 & 0.92 & 31.12 & 0.00 & 100.00 \\
\hline 14.06 & 3.69 & 0.77 & 13.60 & 3.03 & 0.59 & 10.53 & 5.46 & 2.25 & 9.50 & 3.84 & 1.54 & 31.13 & 0.00 & 100.00 \\
\hline 10.76 & 2.83 & 0.59 & 1.60 & 0.36 & 0.07 & 7.68 & 3.98 & 1.64 & 1.15 & 0.46 & 0.19 & 68.70 & 0.00 & 100.00 \\
\hline 34.80 & 9.13 & 1.91 & 3.46 & 0.77 & 0.15 & 12.80 & 6.63 & 2.73 & 1.28 & 0.52 & 0.21 & 25.63 & 0.00 & 100.00 \\
\hline 9.10 & 2.39 & 0.50 & 19.81 & 4.42 & 0.86 & 6.57 & 3.40 & 1.40 & 14.36 & 5.80 & 2.33 & 29.06 & 0.00 & 100.00 \\
\hline 12.08 & 3.17 & 0.66 & 1.84 & 0.41 & 0.08 & 14.13 & 7.32 & 3.02 & 2.25 & 0.91 & 0.36 & 53.77 & 0.00 & 100.00 \\
\hline 4.92 & 1.29 & 0.27 & 12.98 & 2.89 & 0.56 & 7.31 & 3.79 & 1.56 & 19.35 & 7.82 & 3.13 & 34.12 & 0.00 & 100.00 \\
\hline 16.41 & 4.31 & 0.90 & 11.77 & 2.63 & 0.51 & 16.70 & 8.65 & 3.57 & 11.88 & 4.80 & 1.93 & 15.95 & 0.00 & 100.00 \\
\hline 7.73 & 2.03 & 0.42 & 3.96 & 0.88 & 0.17 & 10.39 & 5.38 & 2.22 & 5.34 & 2.16 & 0.87 & 58.44 & 0.00 & 100.00 \\
\hline 22.18 & 5.82 & 1.22 & 22.78 & 5.08 & 0.99 & 10.31 & 5.34 & 2.20 & 10.63 & 4.30 & 1.72 & 7.44 & 0.00 & 100.00 \\
\hline 14.75 & 3.87 & 0.81 & $\begin{array}{l}9.78 \\
\end{array}$ & 2.18 & 0.42 & 10.73 & 5.56 & 2.29 & $\begin{array}{l}8.28 \\
\end{array}$ & 3.35 & 1.34 & 36.64 & 0.00 & 100.00 \\
\hline 19.21 & 4.45 & 0.80 & 11.36 & 2.49 & 0.50 & 11.91 & 4.57 & 1.73 & 6.69 & 2.58 & 1.03 & 28.96 & 3.74 & 100.00 \\
\hline
\end{tabular}

Notes: All figures in percentages except as indicated. Labels used in SAM: L01RMU: Rural Male Unskilled, L02RMM: Rural Male Medium-skilled, L03RMH: Rural Male Highly-skilled, L04UMU: Urban Male Unskilled, L05UMM: Urban Male Medium-skilled, L06UMH: Urban Male Highly-skilled, L07RFU: Rural Female Unskilled, L08RFM: Rural Female Medium-skilled, L09RFH: Rural Female Highly-skilled, L10UFU: Urban Female Unskilled, L11UFM: Urban Female Medium-skilled, L12UFH: Urban Female Highly-skilled. 

Table 6: Export Composition by Trading Partner

(all figures in percentages)

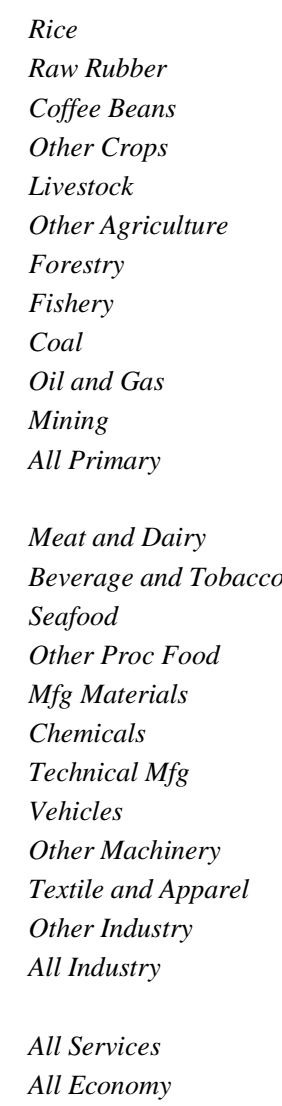

\begin{tabular}{|c|c|c|c|c|c|c|c|c|c|c|c|c|c|}
\hline 1 & 2 & 3 & 4 & 5 & 6 & 7 & 8 & 9 & 10 & 11 & 12 & 13 & 14 \\
\hline ASEAN & Japan & Taiwan & China & HongKong & Korea & OthAsia & $E U$ & EEurope & $A N Z$ & $U S A$ & Canada & LatinAm & ROW \\
\hline 68 & 1 & 0 & 0 & 0 & 0 & 0 & 0 & 7 & 0 & 0 & 0 & 3 & 19 \\
\hline 25 & 2 & 11 & 16 & 5 & 5 & 0 & 22 & 4 & 1 & 2 & 2 & 2 & 1 \\
\hline 6 & 4 & 0 & 0 & 0 & 3 & 0 & 54 & 8 & 4 & 18 & 1 & 0 & 1 \\
\hline 23 & 4 & 13 & 4 & 4 & 6 & 2 & 18 & 4 & 6 & 10 & 1 & 2 & 3 \\
\hline 3 & 15 & 0 & 0 & 42 & 0 & 0 & 4 & 20 & 0 & 12 & 3 & 0 & 0 \\
\hline 0 & 0 & 0 & 0 & 0 & 0 & 0 & 0 & 0 & 0 & 0 & 0 & 0 & 0 \\
\hline 1 & 47 & 29 & 11 & 5 & 5 & 0 & 1 & 0 & 0 & 0 & 0 & 0 & 0 \\
\hline 6 & 45 & 1 & 0 & 7 & 4 & 0 & 16 & 1 & 2 & 14 & 1 & 0 & 0 \\
\hline 12 & 42 & 4 & 1 & 0 & 3 & 0 & 28 & 0 & 0 & 1 & 0 & 5 & 4 \\
\hline 29 & 17 & 0 & 11 & 0 & 1 & 0 & 0 & 0 & 36 & 6 & 0 & 0 & 0 \\
\hline 16 & 18 & 27 & 5 & 0 & 6 & 0 & 2 & 20 & 5 & 0 & 0 & 0 & 0 \\
\hline 19 & 20 & 9 & 5 & 6 & 3 & 0 & 14 & 7 & 5 & 7 & 1 & 1 & 3 \\
\hline 13 & 17 & 0 & 1 & 42 & 0 & 3 & 11 & 3 & 0 & 9 & 1 & 0 & 0 \\
\hline 32 & 26 & 4 & 0 & 16 & 0 & 0 & 8 & 2 & 2 & 10 & 1 & 0 & 0 \\
\hline 6 & 46 & 1 & 0 & 1 & 4 & 0 & 7 & 1 & 1 & 30 & 2 & 0 & 0 \\
\hline 2 & 12 & 28 & 3 & 7 & 2 & 0 & 5 & 36 & 2 & 3 & 1 & 0 & 0 \\
\hline 4 & 10 & 37 & 1 & 1 & 3 & 0 & 30 & 7 & 1 & 1 & 0 & 1 & 2 \\
\hline 19 & 15 & 11 & 10 & 6 & 2 & 0 & 22 & 5 & 3 & 1 & 1 & 3 & 3 \\
\hline 40 & 25 & 1 & 2 & 3 & 3 & 0 & 19 & 2 & 0 & 0 & 1 & 4 & 0 \\
\hline 12 & 5 & 1 & 0 & 11 & 2 & 0 & 18 & 41 & 8 & 0 & 0 & 0 & 0 \\
\hline 17 & 21 & 22 & 2 & 3 & 1 & 0 & 25 & 1 & 2 & 5 & 1 & 0 & 1 \\
\hline 5 & 24 & 7 & 1 & 3 & 4 & 0 & 45 & 3 & 2 & 2 & 3 & 1 & 1 \\
\hline 3 & 9 & 4 & 0 & 1 & 1 & 0 & 65 & 4 & 2 & 6 & 2 & 2 & 2 \\
\hline 14 & 19 & 11 & 2 & 9 & 2 & 0 & 23 & 9 & 2 & 6 & 1 & 1 & 1 \\
\hline 15 & 16 & 5 & 3 & 2 & 2 & 0 & 33 & 3 & 8 & 6 & 1 & 2 & 2 \\
\hline 16 & 18 & 8 & 3 & 6 & 3 & 0 & 24 & 6 & 5 & 6 & 1 & 1 & 2 \\
\hline
\end{tabular}


Table 7: Export Composition by Commodity

(all figures in percentages)

Rice

Raw Rubber

Coffee Beans

Other Crops

Livestock

Other Agriculture

Forestry

Fishery

Coal

Oil and Gas

Mining

All Primary

\begin{tabular}{|c|c|c|c|c|c|c|c|c|c|c|c|c|c|c|}
\hline 1 & 2 & 3 & 4 & 5 & 6 & 7 & 8 & 9 & 10 & 11 & 12 & 13 & 14 & \\
\hline$A S E A N$ & Japan & Taiwan & China & HongKong & Korea & OthAsia & $E U$ & EEurope & $A N Z$ & USA & Canada & LatinAm & $R O W$ & Average \\
\hline 4 & 0 & 0 & 0 & 0 & 0 & 0 & 0 & 1 & 0 & 0 & 0 & 2 & 9 & 1 \\
\hline 2 & 0 & 1 & 4 & 1 & 2 & 2 & 1 & 1 & 0 & 0 & 2 & 2 & 1 & 1 \\
\hline 1 & 1 & 0 & 0 & 0 & 3 & 1 & 6 & 3 & 1 & 7 & 3 & 0 & 2 & 2 \\
\hline 9 & 1 & 8 & 6 & 6 & 11 & 62 & 4 & 3 & 3 & 8 & 5 & 9 & 9 & 10 \\
\hline 0 & 1 & 0 & 0 & 15 & 0 & 0 & 0 & 4 & 0 & 2 & 3 & 0 & 0 & 2 \\
\hline 0 & 0 & 0 & 0 & 0 & 0 & 0 & 0 & 0 & 0 & 0 & 0 & 0 & 0 & 0 \\
\hline 0 & 0 & 0 & 0 & 0 & 0 & 0 & 0 & 0 & 0 & 0 & 0 & 0 & 0 & 0 \\
\hline 1 & 6 & 0 & 0 & 5 & 4 & 0 & 2 & 0 & 1 & 5 & 2 & 0 & 1 & 2 \\
\hline 2 & 5 & 1 & 0 & 0 & 3 & 0 & 2 & 0 & 0 & 0 & 0 & 9 & 6 & 2 \\
\hline 32 & 14 & 0 & 45 & 0 & 6 & 0 & 0 & 0 & 63 & 14 & 0 & 0 & 0 & 12 \\
\hline 0 & 0 & 1 & 0 & 0 & 0 & 0 & 0 & 1 & 0 & 0 & 0 & 0 & 0 & 0 \\
\hline 50 & 28 & 12 & 56 & 27 & 29 & 65 & 15 & 12 & 68 & 38 & 16 & 22 & 29 & 33 \\
\hline
\end{tabular}

Meat and Dairy

Beverage and Tobacco

$\begin{array}{lll}0 & 0 & 0 \\ 2 & 1 & 0\end{array}$

Seafood

Other Proc Food

Mfg Materials

Chemicals

Technical Mfg

Vehicles

Other Machinery

Textile and Apparel

Other Industry

All Industry

All Services

All Economy

$\begin{array}{rrr}2 & 13 & 0 \\ 1 & 7 & 34\end{array}$

$\begin{array}{lll}0 & 0 \\ 0 & 0 & 3\end{array}$

$3 \quad 0$

0
0
7

$\begin{array}{ll}3 & 0 \\ 0 & 0 \\ 0 & \end{array}$

0
0
2

$\begin{array}{lllllll}0 & 0 & 0 & 0 & 0 & 0 & 1\end{array}$

\begin{tabular}{rrr}
1 & 3 & 21 \\
3 & 2 & 3 \\
1 & 1 & 0 \\
1 & 0 & 0 \\
0 & 0 & 0 \\
7 & 21 & 13 \\
0 & 1 & 1 \\
\hline 20 & 49 & 73
\end{tabular}

$\begin{array}{lll}9 & 22 & 7\end{array}$

22

$\begin{array}{lll}6 & 4 & 2 \\ 0 & 0 & 1\end{array}$

0
0

$0 \quad 0$


Table 8: Import Composition by Trading Partner

(all figures in percentages)

Rice

Raw Rubber

Coffee Bean

Livestock

Other Agriculture

Forestry

Fishery

Coal

Oil and Gas

Mining

Average Primary

Meat and Dairy

Beverage and Tobacco

Seafood

Other Proc Food

Mfg Materials

Chemicals

Technical Mfg

Vehicles

Other Machinery

Textile and Apparel

Other Industry

Average Industry

Average Services

All Economy

\begin{tabular}{|c|c|c|c|c|c|c|c|c|c|c|c|c|c|c|}
\hline $\begin{array}{r}1 \\
\text { ASEAN }\end{array}$ & $\begin{array}{r}2 \\
\text { Japan }\end{array}$ & $\begin{array}{r}3 \\
\text { Taiwan }\end{array}$ & $\begin{array}{c}4 \\
\text { China HongKo }\end{array}$ & $\begin{array}{r}5 \\
n g\end{array}$ & $\begin{array}{r}6 \\
\text { Korea }\end{array}$ & $\begin{array}{r}7 \\
\text { OthAsia }\end{array}$ & $\begin{array}{r}8 \\
E U\end{array}$ & $\begin{array}{r}9 \\
\text { EEurope }\end{array}$ & $\begin{array}{r}10 \\
\text { ANZ }\end{array}$ & $\begin{array}{r}11 \\
U S A\end{array}$ & $\begin{array}{r}12 \\
\text { Canada }\end{array}$ & $\begin{array}{r}13 \\
\text { LatinAm }\end{array}$ & $\begin{array}{r}14 \\
\text { ROW }\end{array}$ & Total \\
\hline 4 & 0 & 0 & 96 & 0 & 0 & 0 & 0 & 0 & 0 & 0 & 0 & 0 & 0 & 100 \\
\hline 88 & 1 & 0 & 7 & 0 & 1 & 0 & 0 & 0 & 0 & 2 & 0 & 0 & 2 & 100 \\
\hline 13 & 0 & 0 & 84 & 0 & 0 & 0 & 2 & 1 & 0 & 0 & 0 & 0 & 0 & 100 \\
\hline 13 & 7 & 1 & 26 & 0 & 1 & 0 & 17 & 1 & 24 & 5 & 3 & 2 & 1 & 100 \\
\hline 28 & 1 & 2 & 7 & 0 & 0 & 2 & 20 & 0 & 22 & 12 & 5 & 2 & 0 & 100 \\
\hline 0 & 0 & 0 & 0 & 0 & 0 & 0 & 0 & 0 & 0 & 0 & 0 & 0 & 0 & 0 \\
\hline 64 & 1 & 5 & 1 & 0 & 0 & 0 & 12 & 1 & 7 & 5 & 0 & 3 & 0 & 100 \\
\hline 33 & 0 & 1 & 1 & 7 & 6 & 11 & 7 & 3 & 5 & 8 & 10 & 6 & 3 & 100 \\
\hline 2 & 3 & 5 & 82 & 0 & 0 & 6 & 1 & 1 & 0 & 0 & 0 & 0 & 0 & 100 \\
\hline 71 & 0 & 15 & 0 & 0 & 0 & 0 & 0 & 14 & 0 & 0 & 0 & 0 & 0 & 100 \\
\hline 27 & 1 & 16 & 24 & 0 & 2 & 0 & 7 & 18 & 1 & 2 & 1 & 0 & 2 & 100 \\
\hline 31 & 1 & 4 & 30 & 1 & 1 & 2 & 6 & 3 & 5 & 3 & 2 & 1 & 1 & \\
\hline 12 & 0 & 0 & 4 & 0 & 0 & 0 & 12 & 9 & 53 & 9 & 0 & 0 & 0 & 100 \\
\hline 67 & 0 & 0 & 5 & 22 & 0 & 0 & 4 & 0 & 0 & 0 & 0 & 1 & 0 & 100 \\
\hline 56 & 11 & 2 & 11 & 0 & 1 & 0 & 3 & 0 & 0 & 15 & 0 & 0 & 0 & 100 \\
\hline 58 & 1 & 4 & 6 & 0 & 4 & 0 & 9 & 5 & 6 & 3 & 1 & 3 & 0 & 100 \\
\hline 35 & 7 & 16 & 6 & 1 & 14 & 0 & 8 & 3 & 2 & 3 & 1 & 3 & 0 & 100 \\
\hline 31 & 7 & 11 & 11 & 0 & 12 & 2 & 11 & 6 & 1 & 4 & 1 & 1 & 1 & 100 \\
\hline 32 & 23 & 8 & 4 & 0 & 8 & 1 & 15 & 4 & 1 & 2 & 0 & 0 & 0 & 100 \\
\hline 39 & 10 & 4 & 3 & 1 & 7 & 1 & 13 & 14 & 3 & 3 & 0 & 0 & 1 & 100 \\
\hline 25 & 16 & 16 & 10 & 0 & 12 & 1 & 11 & 3 & 4 & 2 & 0 & 0 & 0 & 100 \\
\hline 8 & 8 & 31 & 27 & 0 & 19 & 0 & 4 & 0 & 1 & 1 & 0 & 0 & 0 & 100 \\
\hline 27 & 4 & 22 & 6 & 1 & 14 & 3 & 8 & 2 & 0 & 6 & 0 & 5 & 1 & 100 \\
\hline 36 & 8 & 10 & 8 & 2 & 8 & 1 & 9 & 4 & 7 & 5 & 0 & 1 & 0 & \\
\hline 28 & 12 & 16 & 9 & 1 & 12 & 1 & 10 & 4 & 2 & 2 & 0 & 1 & 0 & 100 \\
\hline 32 & 7 & 10 & 16 & 1 & 7 & 1 & 8 & 4 & 5 & 3 & 1 & 1 & 1 & 100 \\
\hline
\end{tabular}


Table 9: Import Composition by Commodity

(all figures in percentages)

Rice

Raw Rubber

Coffee Beans

Other Crop

Livestock

Other Agriculture

Forestry

Fishery

Coal

Oil and Gas

Mining

All Primary

Meat and Dairy

Beverage and Tobacco

Seafood

Other Proc Food

Mfg Materials

Chemicals

Technical Mfg

Vehicles

Other Machinery

Textile and Apparel

Other Industry

All Industry

All Services

All Economy

\begin{tabular}{|c|c|c|c|c|c|c|c|c|c|c|c|c|c|c|}
\hline $\begin{array}{r}1 \\
A S E A N\end{array}$ & $\begin{array}{r}2 \\
\text { Japan }\end{array}$ & $\begin{array}{r}3 \\
\text { Taiwan }\end{array}$ & $\begin{array}{c}4 \\
\text { China HongKo }\end{array}$ & $\begin{array}{r}5 \\
n g\end{array}$ & $\begin{array}{r}6 \\
\text { Korea }\end{array}$ & $\begin{array}{r}7 \\
\text { OthAsia }\end{array}$ & $\begin{array}{r}8 \\
E U\end{array}$ & $\begin{array}{r}9 \\
\text { OthEur }\end{array}$ & $\begin{array}{r}10 \\
A N Z\end{array}$ & $\begin{array}{r}11 \\
U S A\end{array}$ & $\begin{array}{r}12 \\
\text { Canada }\end{array}$ & $\begin{array}{r}13 \\
\text { LatinAm }\end{array}$ & $\begin{array}{r}14 \\
R O W\end{array}$ & Average \\
\hline 0 & 0 & 0 & 1 & 0 & 0 & 0 & 0 & 0 & 0 & 0 & 0 & 0 & 0 & 0 \\
\hline 0 & 0 & 0 & 0 & 0 & 0 & 0 & 0 & 0 & 0 & 0 & 0 & 0 & 0 & 0 \\
\hline 0 & 0 & 0 & 0 & 0 & 0 & 0 & 0 & 0 & 0 & 0 & 0 & 0 & 0 & 0 \\
\hline 1 & 1 & 0 & 6 & 0 & 0 & 0 & 4 & 0 & 21 & 5 & 14 & 6 & 2 & 4 \\
\hline 0 & 0 & 0 & 0 & 0 & 0 & 0 & 0 & 0 & 0 & 0 & 1 & 0 & 0 & 0 \\
\hline 0 & 0 & 0 & 0 & 0 & 0 & 0 & 0 & 0 & 0 & 0 & 0 & 0 & 0 & 0 \\
\hline 1 & 0 & 0 & 0 & 0 & 0 & 0 & 0 & 0 & 1 & 1 & 0 & 1 & 0 & 0 \\
\hline 0 & 0 & 0 & 0 & 1 & 0 & 1 & 0 & 0 & 0 & 0 & 2 & 1 & 1 & 0 \\
\hline 0 & 0 & 0 & 0 & 0 & 0 & 0 & 0 & 0 & 0 & 0 & 0 & 0 & 0 & 0 \\
\hline 5 & 0 & 2 & 0 & 0 & 0 & 0 & 0 & 6 & 0 & 0 & 0 & 0 & 0 & 1 \\
\hline 0 & 0 & 0 & 1 & 0 & 0 & 0 & 0 & 1 & 0 & 0 & 0 & 0 & 1 & 0 \\
\hline 7 & 2 & 3 & 7 & 1 & 0 & 1 & 5 & 8 & 22 & 6 & 18 & 8 & 5 & \\
\hline
\end{tabular}

\begin{tabular}{|c|c|c|c|c|c|c|c|c|c|c|c|c|c|c|}
\hline 0 & 0 & 0 & 0 & 0 & 0 & 0 & 1 & 1 & 14 & 2 & 0 & 0 & 0 & 1 \\
\hline 5 & 0 & 0 & 1 & 55 & 0 & 0 & 1 & 0 & 0 & 0 & 0 & 2 & 1 & 5 \\
\hline 0 & 0 & 0 & 0 & 0 & 0 & 0 & 0 & 0 & 0 & 0 & 0 & 0 & 0 & 0 \\
\hline 5 & 0 & 1 & 1 & 1 & 1 & 0 & 2 & 3 & 5 & 3 & 3 & 9 & 0 & 2 \\
\hline 5 & 3 & 5 & 3 & 3 & 5 & 1 & 3 & 3 & 3 & 5 & 9 & 14 & 3 & 5 \\
\hline 19 & 12 & 13 & 19 & 7 & 19 & 40 & 19 & 24 & 3 & 29 & 44 & 11 & 41 & 22 \\
\hline 14 & 28 & 8 & 5 & 5 & 10 & 11 & 19 & 14 & 7 & 10 & 4 & 1 & 6 & 10 \\
\hline 7 & 5 & 2 & 1 & 7 & 3 & 3 & 7 & 17 & 6 & 6 & 3 & 1 & 14 & 6 \\
\hline 16 & 26 & 20 & 16 & 2 & 20 & 11 & 20 & 15 & 23 & 12 & 4 & 6 & 9 & 14 \\
\hline 3 & 9 & 26 & 31 & 2 & 21 & 4 & 4 & 1 & 5 & 4 & 3 & 3 & 3 & 9 \\
\hline 5 & 2 & 8 & 3 & 4 & 6 & 16 & 4 & 3 & 1 & 11 & 2 & 32 & 6 & 7 \\
\hline 80 & 84 & 82 & 81 & 85 & 85 & 86 & 82 & 80 & 68 & 82 & 72 & 80 & 84 & 81 \\
\hline 13 & 15 & 15 & 12 & 14 & 14 & 13 & 14 & 12 & 10 & 12 & 10 & 12 & 11 & 13 \\
\hline 100 & 100 & 100 & 100 & 100 & 100 & 100 & 100 & 100 & 100 & 100 & 100 & 100 & 100 & 100 \\
\hline
\end{tabular}

